\title{
Preparation, crystal structure, and characterization of an inorganic-organic hybrid polyoxoniobate $\left[\mathrm{Cu}(\mathrm{en})_{2}\right]_{3}\left[\mathrm{Cu}(\mathrm{en})_{2}\left(\mathrm{H}_{2} \mathrm{O}\right)\right]_{1 \cdot 5}\left[\mathrm{~K}_{0.5} \mathrm{Nb}_{24} \mathrm{O}_{72} \mathrm{H}_{14 \cdot 5}\right] 2 \cdot 25 \mathrm{H}_{2} \mathrm{O}$
}

\author{
JING-PING WANG, HONG-YU NIU and JING-YANG NIU* \\ Institute of Molecular and Crystal Engineering, School of Chemistry and Chemical Engineering, \\ Henan University, Kaifeng, Henan 475001, PR China \\ e-mail: jyniu@henu.edu.cn
}

MS received 16 October 2007; revised 21 March 2008

\begin{abstract}
An inorganic-organic hybrid polyoxoniobate compound $\left[\mathrm{Cu}(\mathrm{en})_{2}\right]_{3}\left[\mathrm{Cu}(\mathrm{en})_{2}\left(\mathrm{H}_{2} \mathrm{O}\right)\right]_{1.5}$ $\left[\mathrm{K}_{0.5} \mathrm{Nb}_{24} \mathrm{O}_{72} \mathrm{H}_{14.5}\right] 2 \cdot 25 \mathrm{H}_{2} \mathrm{O}$ (1) was synthesized by reaction of $\mathrm{K}_{7} \mathrm{HNb}_{6} \mathrm{O}_{19} \cdot 13 \mathrm{H}_{2} \mathrm{O}, \mathrm{Cu}\left(\mathrm{CH}_{3} \mathrm{COOH}\right)_{2} \cdot \mathrm{H}_{2} \mathrm{O}$ and en (ethylenediamine) in aqueous solution and characterized by IR, ESR spectroscopy and singlecrystal X-ray diffraction method. Structure analysis indicates that compound $\mathbf{1}$ consists of a new type polyoxoniobate anion $\left[\mathrm{K}_{0.5} \mathrm{Nb}_{24} \mathrm{O}_{72} \mathrm{H}_{14.5}\right]^{9-}$, three $\left[\mathrm{Cu}(\mathrm{en})_{2}\right]^{2+}$, one point five $\left[\mathrm{Cu}(\mathrm{en})_{2}\left(\mathrm{H}_{2} \mathrm{O}\right)\right]^{2+}$, and two point two five crystal water molecules. The structure contains $\mathrm{N}-\mathrm{H}$... O hydrogen bonds between the coordinated ethylenediamine and the polyniobate-anion. The whole molecule possesses the $C_{3 v}$ symmetry.
\end{abstract}

Keywords. Polyoxometalates; polyoxoniobate; crystal structure; characterization.

\section{Introduction}

Polyoxometalates (POMs) are a unique class of inorganic metal-oxygen clusters. They have found manifold potential applications in catalysis ${ }^{1-2}$ medicine, ${ }^{3}$ material science, ${ }^{4}$ nuclear waste processing. ${ }^{5}$ Numerous new structural types with fascinating topological beauty and the associated multitude of properties are still being discovered. ${ }^{6-9}$

Polyoxoniobates have been less evolved in comparison with the structural diversities of polyoxotungstates, polyoxomolybdates and polyoxovandates because of the lack of soluble monomeirc precursors and only stable in alkaline media, whereas most other POMs can be easily formed over a wide $\mathrm{pH}$ range. The stability in highly alkaline solutions (polyoxoanions of niobium are stable only in $\mathrm{pH}>10$ basic media) and high surface ratio of polyoxoniobates render them appropriate for radionuclide separation from caustic nuclear wasters, ${ }^{10-12}$ virology ${ }^{13}$ and the base-catalysed de-composition of biocontaminants. ${ }^{14}$ So, more researchers have taken their interest in the study of polyoxoniobate. Here, we have obtained a new inorganic-organic hybrid polyoxoniobate compound $\left[\mathrm{Cu}(\mathrm{en})_{2}\right]_{3}\left[\mathrm{Cu}(\mathrm{en})_{2}\left(\mathrm{H}_{2} \mathrm{O}\right)\right]_{1.5}\left[\mathrm{~K}_{0.5} \mathrm{Nb}_{24} \mathrm{O}_{72} \mathrm{H}_{14.5}\right]$

*For correspondence
$2 \cdot 25 \mathrm{H}_{2} \mathrm{O}(1)$ and characterized by IR, ESR spectroscopy and single-crystal X-ray diffraction method.

\section{Experimental}

All chemicals were purchased from commercial sources and used without further purification. Potassium hexaniobate $\mathrm{K}_{7} \mathrm{HNb}_{6} \mathrm{O}_{19} \cdot 13 \mathrm{H}_{2} \mathrm{O}$ were prepared by literature method. ${ }^{15-16}$ IR spectra were recorded on a Nicolet 170SXFT-IR spectrometer with a $\mathrm{KBr}$ pellet, in the range of $4000 \sim 400 \mathrm{~cm}^{-1}$. EPR spectra were recorded on a Bruker ER-200-DSRC 10 spectrometer at the $\mathrm{X}$-band. Elemental analysis were performed on a Jarrel-Ash J-A1100 spectrometer.

\subsection{Preparation of compound $\mathbf{1}$}

$0.5 \mathrm{~mL}$ en (en = ethylenediamine) was added to an aqueous solution of $\mathrm{Cu}\left(\mathrm{CH}_{3} \mathrm{COO}\right)_{2} \cdot \mathrm{H}_{2} \mathrm{O} \quad(0 \cdot 3 \mathrm{~g}$, $1.5 \mathrm{mmol}$ ) while stirring at room temperature. The resulting purple solution was added drop-wise to a beaker containing an aqueous solution of $\mathrm{K}_{7} \mathrm{HNb}_{6} \mathrm{O}_{19}$. $13 \mathrm{H}_{2} \mathrm{O}(0.68 \mathrm{~g}, 0.5 \mathrm{mmol})$. This solution was stirred at $60^{\circ} \mathrm{C}$ for $4 \mathrm{~h}$ and then evaporated at room temperature. Deep purple single crystals were obtained after a week. Yield: $0.4 \mathrm{~g}$ ( $76 \%$ bases on $\mathrm{Nb})$. IR: 
Table 1. Crystallographic parameters of compound 1.

\begin{tabular}{ll}
\hline Formula & $\mathrm{C}_{18} \mathrm{H}_{94} \mathrm{Cu} 4 \cdot 5 \mathrm{~K}_{0.5} \mathrm{~N}_{18} \mathrm{Nb}_{24} \mathrm{O}_{75 \cdot 75}$ \\
Formula weight & $4310 \cdot 27$ \\
Crystal system & Hexagonal \\
Space group & $R-3$ \\
Unit cell dimensions & \\
$\quad a(\AA)$ & $24 \cdot 506(5)$ \\
$\quad b(\AA)$ & $24 \cdot 506(5)$ \\
$\quad c(\AA)$ & $48 \cdot 175(7)$ \\
$\quad \alpha\left(^{\circ}\right)$ & 90 \\
$\quad \beta\left(^{\circ}\right)$ & 90 \\
$\quad \gamma\left({ }^{\circ}\right)$ & 120 \\
Volume $\left(\AA^{3}\right)$ & $25055(8)$ \\
$Z$ & 6 \\
$D_{\text {calc }}(\mathrm{g}$ cm & $-3)$ \\
Absorption coefficient $\left(\mathrm{mm}{ }^{-1}\right)$ & $1 \cdot 707$ \\
$F(000)$ & $2 \cdot 213$ \\
$\Theta$ range for data collection & 12240 \\
& $2 \cdot 09$ to $25 \cdot 00^{\circ}$ \\
Limiting indices & $-28 \leq h \leq 21$ \\
& $-29 \leq k \leq-29$ \\
Reflections collected & $-57 \leq l \leq 55$ \\
Independent reflections & 37573 \\
Refinement method & 9176 \\
Data/restraints/parameters & Full-matrix least-squares on $F^{2}$ \\
Goodness-of-fit on $F^{2}$ & $9176 / 82 / 544$ \\
Final $R$ indices $[I>2 \sigma(I)]$ & $0 \cdot 891$ \\
Largest diffraction peak and hole & $R 1=0 \cdot 0785, w R_{2}=0 \cdot 2423$ \\
\hline & $1 \cdot 914$ and $-0 \cdot 953$ e $\AA^{-3}$ \\
&
\end{tabular}

$1173(\mathrm{~m}), 1112(\mathrm{~m}), 1045(\mathrm{~s}), 864(\mathrm{~m}), 728(\mathrm{~s}), 647$ $(\mathrm{s}), 524(\mathrm{~m}) \mathrm{cm}^{-1}$. Elemental analysis calc. (\%) for $\mathrm{C}_{18} \mathrm{H}_{94} \mathrm{Cu}_{4.5} \mathrm{~K}_{0.5} \mathrm{~N}_{18} \mathrm{Nb}_{24} \mathrm{O}_{75.75}$ : C, 5.02\%; H, 2.20\%; N, 5.85\%. Found: C, $4.99 \%$; H, $2 \cdot 26 \%$, N, $5 \cdot 83 \%$.

\subsection{Single crystal X-ray diffractometry}

Single crystal of compound $\mathbf{1}$ was mounted on a SMART Apex-II CCD detector using graphite monochromatized MoK $\alpha$ radiation $(\lambda=0.71073 \AA)$ at 293(2) K. The structures were solved by direct methods and refined by the full-matrix least-squares method on $F^{2}$ using the SHELXTL-97 package. ${ }^{17}$ Intensity data were corrected for Lorentz and polarization effects as well as for empirical absorption. All of the non-hydrogen atoms were refined anisotropically. Hydrogen atoms were not included in the refinements. The organic hydrogen atoms were generated geometrically. Details for the structural determination of compound $\mathbf{1}$ are listed in table 1. Selected bond distances for compound $\mathbf{1}$ are represented in table 2 .

\section{Results and discussion}

The X-ray diffraction analysis indicates that compound 1 contains a $\left[\mathrm{K}_{0.5} \mathrm{Nb}_{24} \mathrm{O}_{72}\right]^{23 \cdot 5-}$ polyoxoanion, three $\left[\mathrm{Cu}(\mathrm{en})_{2}\right]^{2+}$, one point five $\left[\mathrm{Cu}(\mathrm{en})_{2}\left(\mathrm{H}_{2} \mathrm{O}\right)\right]^{2+}$ cations and two point two five water molecules. The $\left[\mathrm{K}_{0.5} \mathrm{Nb}_{24} \mathrm{O}_{72}\right]$ unit could be described as three $\left[\mathrm{Nb}_{7} \mathrm{O}_{22}\right]$ units linked alternately by three $\mathrm{Nb}(8) \mathrm{O}_{6}$ octahedra via corner-sharing (see figure 1). The fundamental building block $\left[\mathrm{Nb}_{7} \mathrm{O}_{22}\right]$ is derived from the Lindqvist $\left[\mathrm{Nb}_{6} \mathrm{O}_{19}\right]$ clusters (figure 2), three adjacent bridging oxygen atoms of which are combined with the seventh $\mathrm{Nb}$ atom, $\mathrm{Nb} 7$. Three $\left[\mathrm{Nb}_{7} \mathrm{O}_{22}\right]$ subunits are linked alternately by the $\mathrm{Nb}(8) \mathrm{O}_{6}$ octahedron via sharing two corners and formed a cavity in the center. And $\mathrm{K}^{+}$, with the occupy ratio of 0.5 , locates in the center of the cavity via combined with nine oxygen atoms from $\left[\mathrm{Nb}_{24} \mathrm{O}_{72}\right]$ unit. Thus, the $\left[\mathrm{K}_{0.5} \mathrm{Nb}_{24} \mathrm{O}_{72}\right]^{23.5-}$ polyoxoanion constructs a discrete triangular 'bowl-shaped' cluster structure approaching the $\mathrm{C}_{3 \mathrm{v}}$ point symmetry.

The fourteen point five protons that are added into per $\left[\mathrm{K}_{0.5} \mathrm{Nb}_{24} \mathrm{O}_{72}\right]$ unit (i.e. $\left[\mathrm{K}_{0.5} \mathrm{Nb}_{24} \mathrm{O}_{72} \mathrm{H}_{14.5}\right]^{-9}$ ) are based on charge-balance considerations of compound 1 , because the high number of crystalographically independent atoms and variable parameters prevented direct location of the protons from the Fourier maps, as the description of Nyman. ${ }^{18}$ The three long $\mathrm{Nb}-\mathrm{O}_{\mathrm{t}}$ bonds of the $\mathrm{NbO}_{6}$ octahedra, which linked alternately to three $\left[\mathrm{Nb}_{7} \mathrm{O}_{22}\right]^{9-}$ building 
Table 2. Selected bond lengths $[\AA]$ for 1 .

\begin{tabular}{llll}
\hline $\mathrm{Cu}(1)-\mathrm{N}(1)$ & $1 \cdot 986(14)$ & $\mathrm{Cu}(1)-\mathrm{N}(1) \# 1$ & $1 \cdot 986(14)$ \\
$\mathrm{Cu}(1)-\mathrm{N}(2)$ & $2 \cdot 014(16)$ & $\mathrm{Cu}(1)-\mathrm{N}(2) \# 1$ & $2 \cdot 014(16)$ \\
$\mathrm{Cu}(2)-\mathrm{N}(3)$ & $2 \cdot 03(3)$ & $\mathrm{Cu}(2)-\mathrm{N}(5)$ & $2 \cdot 04(2)$ \\
$\mathrm{Cu}(2)-\mathrm{N}(4)$ & $2 \cdot 05(3)$ & $\mathrm{Cu}(2)-\mathrm{N}(6)$ & $2 \cdot 07(3)$ \\
$\mathrm{Cu}(2)-\mathrm{O}(1 \mathrm{~W})$ & $2 \cdot 37(2)$ & $\mathrm{Cu}(3)-\mathrm{N}(9)$ & $1 \cdot 95(2)$ \\
$\mathrm{Cu}(3)-\mathrm{N}(8)$ & $1 \cdot 99(3)$ & $\mathrm{Cu}(3)-\mathrm{N}(10)$ & $2 \cdot 05(3)$ \\
$\mathrm{Cu}(3)-\mathrm{N}(7)$ & $2 \cdot 29(3)$ & $\mathrm{K}(1)-\mathrm{O}(7 \mathrm{C})$ & $2 \cdot 789(11)$ \\
$\mathrm{K}(1)-\mathrm{O}(7 \mathrm{C}) \# 2$ & $2 \cdot 789(11)$ & $\mathrm{K}(1)-\mathrm{O}(7 \mathrm{C}) \# 3$ & $2 \cdot 789(11)$ \\
$\mathrm{K}(1)-\mathrm{O}(7 \mathrm{~A})$ & $3 \cdot 015(10)$ & $\mathrm{K}(1)-\mathrm{O}(7 \mathrm{~A}) \# 2$ & $3 \cdot 015(10)$ \\
$\mathrm{K}(1)-\mathrm{O}(7 \mathrm{~A}) \# 3$ & $3 \cdot 015(10)$ & $\mathrm{K}(1)-\mathrm{O}(8 \mathrm{~A})$ & $3 \cdot 365(17)$ \\
$\mathrm{K}(1)-\mathrm{O}(8 \mathrm{~A}) \# 2$ & $3 \cdot 365(17)$ & $\mathrm{K}(1)-\mathrm{O}(8 \mathrm{~A}) \# 3$ & $3 \cdot 365(17)$ \\
$\mathrm{Nb}(1)-\mathrm{O}(1)$ & $1 \cdot 753(12)$ & $\mathrm{Nb}(1)-\mathrm{O}(9)$ & $1 \cdot 962(11)$ \\
$\mathrm{Nb}(1)-\mathrm{O}(10)$ & $2 \cdot 016(10)$ & $\mathrm{Nb}(1)-\mathrm{O}(11)$ & $2 \cdot 038(10)$ \\
$\mathrm{Nb}(1)-\mathrm{O}(12)$ & $2 \cdot 068(11)$ & $\mathrm{Nb}(1)-\mathrm{O}(21)$ & $2 \cdot 406(9)$ \\
$\mathrm{Nb}(2)-\mathrm{O}(2)$ & $1 \cdot 763(11)$ & $\mathrm{Nb}(2)-\mathrm{O}(17)$ & $1 \cdot 999(10)$ \\
$\mathrm{Nb}(2)-\mathrm{O}(13)$ & $2 \cdot 004(11)$ & $\mathrm{Nb}(2)-\mathrm{O}(9)$ & $2 \cdot 019(11)$ \\
$\mathrm{Nb}(2)-\mathrm{O}(16)$ & $2 \cdot 047(10)$ & $\mathrm{Nb}(2)-\mathrm{O}(21)$ & $2 \cdot 450(10)$ \\
$\mathrm{Nb}(3)-\mathrm{O}(3)$ & $1 \cdot 776(11)$ & $\mathrm{Nb}(3)-\mathrm{O}(13)$ & $1 \cdot 952(12)$ \\
$\mathrm{Nb}(3)-\mathrm{O}(10)$ & $1 \cdot 990(11)$ & $\mathrm{Nb}(3)-\mathrm{O}(18)$ & $2 \cdot 035(10)$ \\
$\mathrm{Nb}(3)-\mathrm{O}(14)$ & $2 \cdot 057(10)$ & $\mathrm{Nb}(3)-\mathrm{O}(21)$ & $2 \cdot 444(9)$ \\
$\mathrm{Nb}(4)-\mathrm{O}(4)$ & $1 \cdot 831(9)$ & $\mathrm{Nb}(4)-\mathrm{O}(14)$ & $1 \cdot 915(9)$ \\
$\mathrm{Nb}(4)-\mathrm{O}(11)$ & $1 \cdot 926(9)$ & $\mathrm{Nb}(4)-\mathrm{O}(15)$ & $2 \cdot 111(10)$ \\
$\mathrm{Nb}(4)-\mathrm{O}(19)$ & $2 \cdot 124(9)$ & $\mathrm{Nb}(4)-\mathrm{O}(21)$ & $2 \cdot 284(10)$ \\
$\mathrm{Nb}(5)-\mathrm{O}(5)$ & $1 \cdot 835(9)$ & $\mathrm{Nb}(5)-\mathrm{O}(16)$ & $1 \cdot 871(10)$ \\
$\mathrm{Nb}(5)-\mathrm{O}(12)$ & $1 \cdot 904(10)$ & $\mathrm{Nb}(5)-\mathrm{O}(15)$ & $2 \cdot 033(9)$ \\
$\mathrm{Nb}(5)-\mathrm{O}(20)$ & $2 \cdot 084(9)$ & $\mathrm{Nb}(5)-\mathrm{O}(21)$ & $2 \cdot 299(9)$ \\
$\mathrm{Nb}(6)-\mathrm{O}(6)$ & $1 \cdot 760(9)$ & $\mathrm{Nb}(6)-\mathrm{O}(18)$ & $1 \cdot 929(9)$ \\
$\mathrm{Nb}(6)-\mathrm{O}(17)$ & $1 \cdot 935(11)$ & $\mathrm{Nb}(6)-\mathrm{O}(19)$ & $2 \cdot 094(8)$ \\
$\mathrm{Nb}(6)-\mathrm{O}(20)$ & $2 \cdot 104(8)$ & $\mathrm{Nb}(6)-\mathrm{O}(21)$ & $2 \cdot 398(9)$ \\
$\mathrm{Nb}(7)-\mathrm{O}(7 \mathrm{~B})$ & $1 \cdot 805(10)$ & $\mathrm{Nb}(7)-\mathrm{O}(7 \mathrm{~A})$ & $1 \cdot 910(9)$ \\
$\mathrm{Nb}(7)-\mathrm{O}(7 \mathrm{C})$ & $1 \cdot 951(10)$ & $\mathrm{Nb}(7)-\mathrm{O}(20)$ & $2 \cdot 119(10)$ \\
$\mathrm{Nb}(7)-\mathrm{O}(19)$ & $2 \cdot 143(8)$ & $\mathrm{Nb}(7)-\mathrm{O}(15)$ & $2 \cdot 296(10)$ \\
$\mathrm{Nb}(8)-\mathrm{O}(8 \mathrm{~B})$ & $1 \cdot 779(11)$ & $\mathrm{Nb}(8)-\mathrm{O}(7 \mathrm{C})$ & $1 \cdot 965(10)$ \\
$\mathrm{Nb}(8)-\mathrm{O}(7 \mathrm{~A}) \# 3$ & $1 \cdot 982(10)$ & $\mathrm{Nb}(8)-\mathrm{O}(5)$ & $2 \cdot 073(10)$ \\
$\mathrm{Nb}(8)-\mathrm{O}(4) \# 3$ & $2 \cdot 094(9)$ & $\mathrm{Nb}(8)-\mathrm{O}(8 \mathrm{~A})$ & $2 \cdot 428(11)$ \\
$\mathrm{Svm}-$ & & & \\
& & &
\end{tabular}

Symmetry transformations used to generate the equivalent atoms $\# 1-x+1 / 3$, $-y-4 / 3,-z-1 / 3 \quad \# 2-x+y+1,-x-1, z \quad \# 3-y-1, x-y-2, z$

Table 3. Geometrical parameters of hydrogen bonds for compound 1 ( $\AA$, deg).

\begin{tabular}{lccccc}
\hline D-H & A & d(D-H) & H $\cdots A$ & $<$ D-H-A & D $\cdots A$ \\
N7-H7C & O11 & 0.859 & 1.994 & 141.78 & 2.721 \\
N1-H1C & O18 & 0.860 & $2 \cdot 249$ & 144.54 & 2.991 \\
\hline
\end{tabular}

block, are all $2.428 \AA$ as a result of symmetry transformations. Bond valence sum ${ }^{19}$ calculations provide value of 0.247 for these $\mathrm{Nb}-\mathrm{O}_{\mathrm{t}}$ terminal oxygen atoms and indicates the most obvious site for protonation. The BVS values of the remaining terminal oxygen atom in the range of $1.33-1.53$, suggesting that some terminal oxygen atoms can be monoprotonated. However, bond-valence calculations did not provide an obvious solution as a result of a typical distor- tions and the relatively wide variation of the $\mathrm{Nb}-\mathrm{O}$ bond lengths ${ }^{18-19}$ (table 2). Although they cannot be accurately located by X-ray and BVS calculations, these protons must be localized or delocalized in polyoxoniobate anion units. ${ }^{18,20}$

The $\left[\mathrm{Cu}(\mathrm{en})_{2}\right]$ and $\left[\mathrm{Cu}(\mathrm{en})_{2}\left(\mathrm{H}_{2} \mathrm{O}\right)\right]$ fragments are distributed symmetrically around the 'bowl'. And $\mathrm{Cu}(1)$ and $\mathrm{Cu}(3)$ atoms are coordinated separately by four nitrogen atoms from two en molecules displaying a $\mathrm{CuN}_{4}$ square planar geometry. $\mathrm{Cu}(2)$ is linked to four nitrogen atoms from two en ligands and one oxygen atom from the water molecule exhibiting a $\mathrm{CuN}_{4} \mathrm{O}$ square pyramid geometry. The $\left[\mathrm{Cu}(\mathrm{en})\left(\mathrm{H}_{2} \mathrm{O}\right)\right]$ fragment combines with the polyoxoanion $\left[\mathrm{K}_{0.5} \mathrm{Nb}_{24} \mathrm{O}_{72} \mathrm{H}_{14.5}\right]^{-9}$ via $\mathrm{N}(7)-\mathrm{H}(7 \mathrm{C}) \cdots \mathrm{O}(11)$ hydrogen bond. Neighbouring polyoxoanion $\left[\mathrm{K}_{0.5} \mathrm{Nb}_{24}\right.$ 
$\left.\mathrm{O}_{72} \mathrm{H}_{14.5}\right]^{-9}$ are linked together by $\left[\mathrm{Cu}(1)(\mathrm{en})_{2}\right]$ via weak $\mathrm{Cu}-\mathrm{O}_{19} \quad(3.260 \AA)$ bond and $\mathrm{N}(1)-$ $\mathrm{H}(1 \mathrm{C}) \cdots \mathrm{O}(18)$ hydrogen bond, resulting in a $2 \mathrm{D}$ interlaced layer (figure 3 ). The disorder water molecules fill in the space of the layers. The hydrogen bonding parameters for compound $\mathbf{1}$ are presented in table 3.

The ESR spectra of compound 1 at room temperature and $110 \mathrm{~K}$ are shown in figure 4 . The spectra at room temperature (figure 4a) exhibit the axial feature (as expected for a square pyramid and square

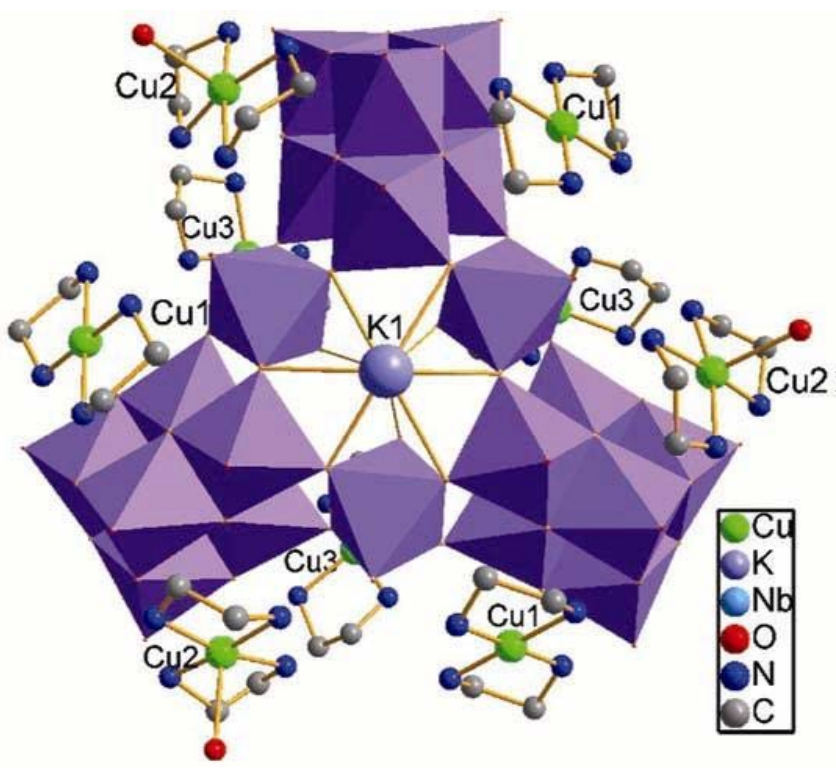

Figure 1. View of the molecule structure of compound 1 (H atom and water molecules are omitted for clarity).

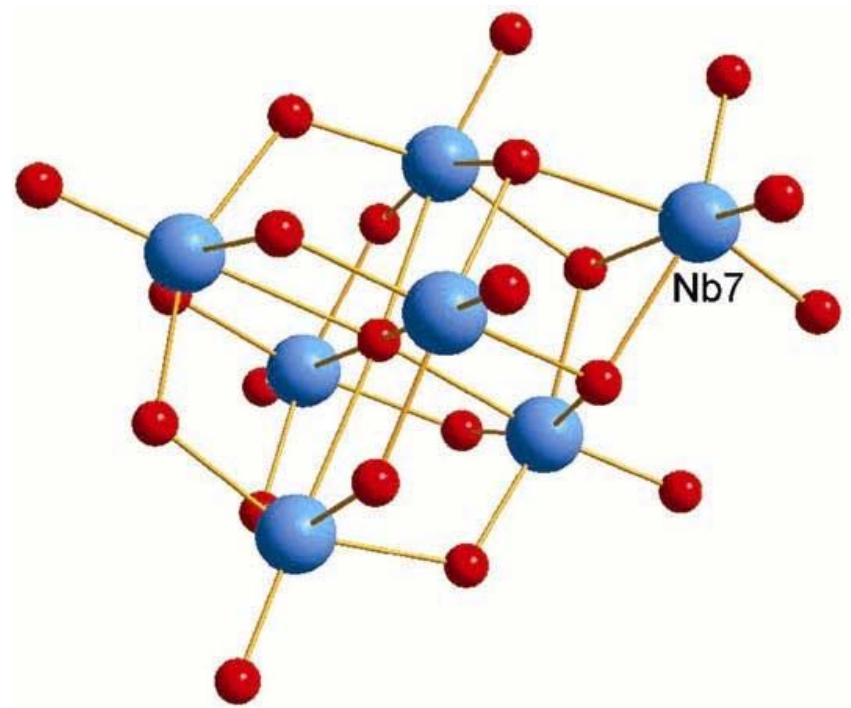

Figure 2. Structure unit of the $\mathrm{Nb}_{7} \mathrm{O}_{22}$. plane $\mathrm{Cu}^{2+}$ center) with $g=2 \cdot 04$. At the lower $110 \mathrm{~K}$ the spectra (figure $4 \mathrm{~b})$ remain same $(g=2 \cdot 10)$. The ESR parameters are in good agreement with those of $\mathrm{Cu}^{2+}\left(\mathrm{d}^{9}\right)$ systems in the literature. ${ }^{21}$

\section{Conclusions}

In this paper we have prepared a new inorganicorganic hybrid polyoxoniobate compound and enriched polyoxoniobates chemsitry. We compared compound 1 with the previously reported polyoxoniobate anion $\left[\mathrm{Nb}_{24} \mathrm{O}_{72} \mathrm{H}_{9}\right]^{15-}(\mathbf{2}){ }^{18}\left[\mathrm{Nb}_{24} \mathrm{O}_{72} \mathrm{H}_{21.5}\right]^{2.5-}(\mathbf{3}),{ }^{20}$ and dimeric fragment $\left[\left(\left\{\mathrm{KNb}_{24} \mathrm{O}_{72} \mathrm{H}_{10.25}\right\}\left\{\mathrm{Cu}(\mathrm{en})_{2}\right\}\right)_{2}\right.$ $\left.\left\{\mathrm{Cu}_{3}(\mathrm{en})_{3}\left(\mathrm{H}_{2} \mathrm{O}\right)_{3}\right\}\left\{\mathrm{Na}_{1.5} \mathrm{Cu}_{1.5}\left(\mathrm{H}_{2} \mathrm{O}\right)_{8}\right\}\right]^{11-}(4){ }^{20}$ Both 1 and 4 use the potassium salts of hexaniobate as pre-

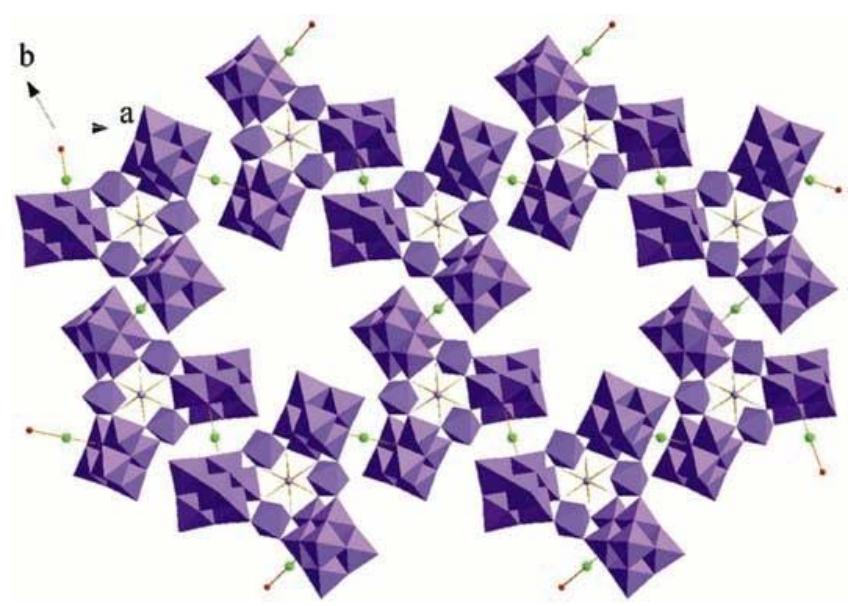

Figure 3. The 2D interlaced layer of compound 1 (C, $\mathrm{H}, \mathrm{N}$ atoms and hydrogen bond are omitted for clarity).

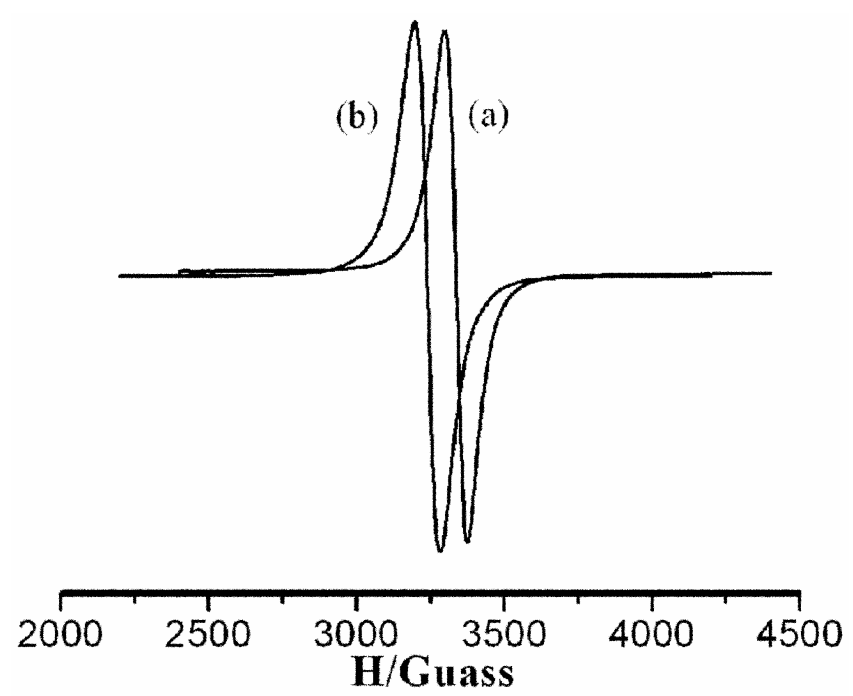

Figure 4. ESR spectra of compound 1. 
cursors and have the $\mathrm{K}^{+}$cation located at the center of the aperture of the $\left\{\mathrm{Nb}_{24} \mathrm{O}_{72}\right\}$ unit. However, 2 and 3 adopt the sodium or rubidium salts and there is no cation located at the aperture center. These indicate the aperture that possesses selectivity for $\mathrm{K}^{+}$cation and could deduce the potential application of the polyoxoniobate in the transport of (biologically relevant) cations.

\section{Acknowledgements}

This work was supported by the Nature Science Foundation of China, the Program for New Century Excellent Talent in University of Hennan Province, and the Natural Science Foundation of Henan Province.

\section{Supplementary material}

CCDC-664094 contains the supplementary crystallographic data for the structure reported in this paper. These data can be obtained free of charge at www. ccdc.cam.ac.uk/conts/retriving.html (or from the Cambridge Crystallographic Data Center (CCDC), 12 Union Road, Cambridge CB2 1EZ, UK; fax: +44(0)1223-336033; email: deposit@ ccdc.cam.ac.uk).

\section{References}

1. Mizuno N and Misono M 1998 Chem. Rev. 98199

2. Xu L, Boring E and Hill C L 2000 J. Catal. 195394

3. Rhule J T, Hill C L and Judd D A 1998 Chem. Rev. 98327
4. Coronado E and Gomez-Garcia C J 1998 Chem. Rev. 98273

5. Besserguenev A V, Dickman $\mathrm{MH}$ and Pope $\mathrm{MT}$ 2001 Inorg. Chem. 402582

6. Jiang C C, Wei Y G, Zhang S W, Liu Q, Shao M C and Tang Y Q 1998 Chem. Commun. 1937

7. Müller A, Shah S Q N, Bogge H and Schmidtman M 1999 Nature 39748

8. Botar B, KOgerler P and Hill C L $2006 \mathrm{~J}$. Am. Chem. Soc. 1285336

9. Mal S S and Kortz U 2005 Angew. Chem. Int. Ed. 44 3777

10. Bonhomme F, Larentzos J P, Alam T M, Maginn E J and Nyman M 2005 Inorg. Chem. 441774

11. Dickman M H and Pope M T 2001 Inorg. Chem. 40 2582

12. Cjoamg M H, Williams C W, Soderhlm L and Antonio M R 2003 Eur. J. Inorg. Chem. 142663

13. Rhule J T, Hill C L and Judd D A 1998 Chem. Rev. 98327

14. Russell A J, Berberich J A, Drevon G F and Koepsel R R 2003 Annu. Rev. Biomed. Eng. 51

15. Flynn C M and Stucky G D 1969 Inorg. Chem. 8 178

16. Filowitz M, Ho R K C, Klemperer W G and Shum W 1979 Inorg. Chem. 1893

17. Sheldrick G M 1997 SHELXL 97: Program for crystal structure refinement, University of Göttingen, Germany

18. Bontchev R P and Nyman M 2006 Angew. Chem. Int. Ed. 456670

19. Brown I D and Altermatt D 1985 Acta Crystallogr. B41 244

20. Niu J Y, Ma P T, Niu H Y, Li J, Zhao J W, Song Y and Wang J P 2007 Chem. Eur. J. DOI: 10.1002/ chem. 200700612

21. Tyagi S and Hathaway B J 1983 J. Chem. Soc., Dalton Trans. 2693 